Politics and Society in Contemporary

Africa 
THIRD EDITION

\section{Politics and Society}

in Contemporary

Africa

Naomi Chazan

Peter Lewis

Robert Mortimer

Donald Rothchild

Stephen John Stedman

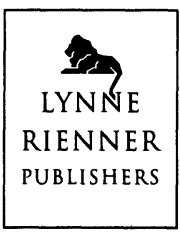

B O U L E R 
Published in the United States of America in 1999 by Lynne Rienner Publishers, Inc.

1800 30th Street, Boulder, Colorado 80301

() 1999 by Lynne Rienner Publishers, Inc. All rights reserved

\section{Library of Congress Cataloging-in-Publication Data}

Politics and society in contemporary Africa / Naomi Chazan ... [et

al.]. - 3rd ed.

Includes bibliographical references and index.

ISBN 978-1-55587-668-5 (hc : alk. paper)

ISBN 978-1-55587-679-1 (pb : alk. paper)

1. Africa-Politics and government-1960- 2. Africa-Social conditions-1960- 3. Africa-Economic conditions-1960- 4. AfricaForeign relations-1960- I. Chazan, Naomi, 1946- . JQ1875.P635 1999

$320.96^{\prime} 09^{\prime} 045-\mathrm{dc} 21$

99-24154

Published and distributed in Europe by

THE MACMILLAN PRESS LTD

Houndmills, Basingstoke, Hampshire RG21 6XS, England, and London

Companies and representatives throughout the world

ISBN 978-0-333-69475-6 ISBN 978-1-349-14490-7 (eBook)

DOI 10.1007/978-1-349-14490-7

A catalogue record for this book is available from the British Library.

The paper used in this publication meets the requirements

(2) of the American National Standard for Permanence of Paper for Printed Library Materials Z39.48-1984. 


\section{Contents}

List of Tables

ix

Map of Africa

Introduction

1 The Diversity of African Politics: Trends and Approaches

Independent Africa: Trends and Patterns, 6

Approaches to the Study of African Politics, 14

The Political Interaction Framework, 23

\section{PART I THE STRUCTURES OF POLITICS}

2 State Institutions and the Organization of the Public Arena

The Concept of the State in Africa, 38

The Structural Foundations of African States:

The Colonial Legacy, 42

Constructions of the Public Arena Since Independence, 46

States and State Variety in Africa:

Some Implications, 68

3 Social Groupings

Social Groups and Social Process, 76

The Organization of Social Life, 79

Social Networks and Social Trends, 100

4 Ethnicity, Class, and the State

Ethnicity and Ethnic Group, 108

The Ethnic Intermediary's Critical Role, 112 
African Class Cleavages and Social Conflicts, 119

Class and Ethnicity as Situational Variables, 127

\section{PART 2 POLITICAL PROCESS AND POLITICAL CHANGE}

5 Regimes in Independent Africa

Regime Evolution in Postcolonial Africa, 139

Regime Types and Their Variations, 141

Regime Types and Political Process, 155

6 High Politics: The Procedures and Practices of Governmen

The Politics of the Center: Decisionmaking and the

Rules of the Political Game, 160

The Politics of Social Relations, 176

Consolidation and Maintenance of the Political Center:

Some Trends, 190

7 Deep Politics: Political Response, Protest, and Conflict

Elite Conflicts, 198

Factional Conflicts, 201

Communal Conflicts, 206

Mass Conflicts, 211

Popular Conflicts, 213

The Interplay of Political Conflicts, 216

8 Political Transitions and Patterns of Change

Modes of Political Change, 222

Patterns of Political Interaction, 230

\section{PART 3 POLITICAL ECONOMY}

9 Coping with Transformation: Approaches to Development

The Range of Choice, 240

Africa in the World Economy, 244

Regimes, Ideology, and Development Strategies, 263

Sectoral Policies, 275

10 Coping with Change: Crisis and Attempted Reform

Managing Dependence: National Strategies, 306

Strategies Toward Foreign Capital, 307

Collective Strategies: Regional Integration, 310

Africa and North-South Relations, 319

Africa's Economic Crisis, 325

Structural Adjustment and the International Financial Institutions, 333 Economic Reform and Democratization, 349 


\section{PART 4 INTERNATIONAL RELATIONS}

11 Inter-African Relations

Trans-Saharan Africa, 364

Central Africa, 387

Southern Africa, 394

Inter-African Politics in the Waning Cold War Era, 405

Inter-African Politics in the Post-Cold War Environment, 408

Conclusion, 414

12 Africa in World Politics

Africa and Europe, 422

Soviet-U.S. Competition in Africa, 431

Détente in Africa, 449

Africa in the New Multipolar System, 451

Conclusion: Africa Among the Lesser Powers, 455

\section{PART 5 POLITICAL FUTURES}

13 South Africa: The Possibilities and Limits of Transforming State and Society

The Historical Formation of a Dual Society, 466

Apartheid's Contradictions and Black Resistance, 473

Negotiations for a New Constitution, 477

The Challenge of Transformation, 484

14 Africa in the Twenty-First Century

Appendix 1: Acronyms

Appendix 2: Changes in Country Names 503

Appendix 3: Basic Political Data 505

Index $\quad 527$

About the Book 545 


\section{Tables}

1.1 Basic Economic Characteristics of African States 8

1.2 Basic Social Characteristics of African States 10

2.1 Relative Burden of Military Expenditures in

Sub-Saharan Africa

5.1 Typology of Regimes 141 


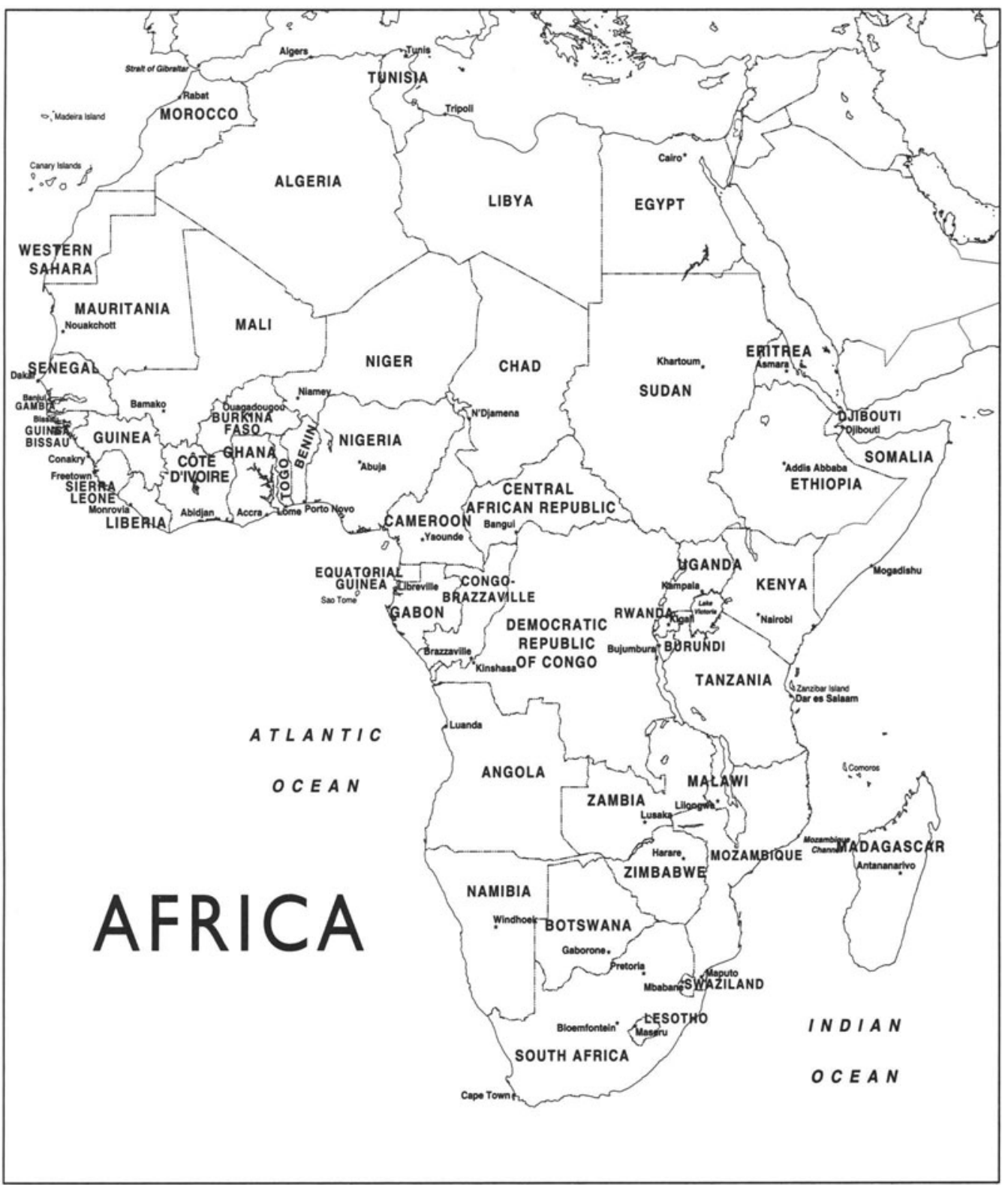

